\title{
Relationship between Business Intelligence and Supply Chain Management for Marketing Decisions
}

\author{
Neven Šrić ${ }^{1}{ }^{\text {* }}$, Ante Rozga ${ }^{1}$, Ante Luetić ${ }^{2}$ \\ ${ }^{1}$ Faculty of Economics, University of Split, Cvite Fiskovića 5 \\ ${ }^{2}$ Split Shipyard,Put Supavla 21. \\ *Corresponding Author: neven.seric@efst.hr
}

Copyright (C) 2014 Horizon Research Publishing All rights reserved.

\begin{abstract}
The companies that apply the concept of business intelligence in their marketing decisions in some of the following ways were included in this study: at the level of the entire system or specific marketing strategy of companies (e.g. marketing department, research development, commercial, etc.), apply business intelligence only in certain marketing processes or projects, used in business from the technology and platform for data warehouse, data mining, OLAP tools, using advanced analytical techniques of simulation and visualization applications. Variables examined were categorized into four groups: business intelligence, supply chain management, information visibility and integration. Factor analysis was used to facilitate the connection of these groups of variables, i.e. reduction of number of variables. Then, we tested the correlation between the newly formed variables. There was a significant statistical correlation between business intelligence, supply chain management, information visibility and integration among the partners in the production chain. ANOVA was conducted to compare differences in the mean values of variables in relation to the activity, size and legal form. This paper will analyze the relationship between business intelligence and supply chain management for strategic and tactic marketing decisions.
\end{abstract}

Keywords Business Intelligence, Supply Chain Management, Factor Analysis, Correlation, Marketing Decisions

\section{Introduction}

In the context of this research business intelligence is seen as a concept of conscious, organized, continuous, legal and legitimate gathering, analyzing and using data and information for strategic and tactics marketing decisions. It is carried out using information technology, but also in other ways. It is aimed to collect the relevant knowledge about customers, suppliers, competitors, and other market factors that directly or indirectly affect the company's business, and to support marketing managers in making strategic and tactic decisions. The purpose of this study was to capture the companies that apply the concept of business intelligence in their business. While researching on the orientation on supply chain and supply chain management, companies selected were those which have been able to confirm that they have at least one link in the supply chain in order to be included in the sample. Also, they were supposed to be active when applying business intelligence for marketing function.

\section{Sample Selection and Questionnaire}

For the purpose of this paper the most interesting empirical statistical research involve survey sampling. The questionnaire was verified by several professors from Faculty of Economics in Split and Zagreb, Faculty of Social Sciences in Zagreb as well as practitioners of business intelligence.

Before the final definition of the survey, pilot study was conducted by the interviewer to test questions on a smaller number of respondents. The purpose of this pre-testing was confirmation of the basic assumptions of the proposed model, validation of the research instrument and remove the ambiguity. In addition to the implementation, the purpose was to determine its clarity and appropriateness for the research. The method of data collection was via internet.

321 enterprises responded to the questionnaire. Given that the intention was to investigate those companies that apply business intelligence in their marketing work, prior to processing we exempt companies that replied to the questionnaire's last assertion of business intelligence ("In your enterprise business intelligence is not yet systematically organized"). There were 25 companies as such. In addition to these companies, the exempted were three who had not responded to this question, which means that the usable responses was 293 , and the response was achieved by $29.3 \%$. As expected response rate for online surveys is variable, in the case of $30 \%$ of companies it is considered to be acceptable.

The main instrument for the implementation of this study 
was a questionnaire consisting of closed questions with multiple choice answers that involve using a Likert scale with five degrees of intensity. Likert scale attitude is based on the assumption that every statement/particles on the scale has equal importance and weight in terms of how much reflects the attitude toward a particular issue or problem. The survey participants have to chose the answer from $1=$ strongly disagree to $5=$ strongly agree. For the purposes of this research, a measurement of the perception of respondents was employed. This was chosen for two reasons: (1) the effects of the use of business intelligence are intangible or qualitative, which are not suitable for the objective measurement, (2) most of the information by their nature confidential or strategic, is therefore not suitable for publication. Studies have shown that managerial assessment and management estimates do not differ significantly from the objective values obtained from external sources.

\section{Creating Variables Related To Business Intelligence}

Claims related to business intelligence are grouped into five groups. Internal consistency was examined using Cronbach's alpha. The first group includes claims related to the sources and reliability of data and information. There is at the beginning of a total of eight variables. Crobach's alpha was calculated to examine internal consistency and it was concluded that one variable should be dropped. Thereafter obtained a satisfactory size Cronbach's alpha (0.715).The second group includes claims related to access to data and information. There were four claims. Cronbach's alpha was 0.77 .

The third group of variables is made of claims relating to advanced analytics. There were also four claims. Cronbach's alpha was 0.778 .

The fourth group includes claims related to intuition and time and consists of five claims. Cronbach's alpha was 0.765 .

The fifth group consists of claims related to the organization of business intelligence and consists of five claims of which one is expelled because of internal inconsistencies. Cronbach's alpha was 0.64.

After testing the internal consistency, factor analysis was performed in order to create five latent variables to facilitate handling in the later stage of analysis. All the results were satisfactory in accordance with the requirements of factor analysis. Main indicators considered about the validity of factor analysis were: Kaiser-Meyer-Olkin measure of sampling adequacy, Bartlett's test of sphericity, Kaiser's criterion on the size of eigenvalues and the percentage of variance explained. Factor loadings were all greater than 0.5 , which is very satisfactory.

\section{Creating Variables Related to Supply Chain Management}

Claims relating to the management of the supply chain are grouped into five dimensions. The first dimension is related to agility and had four claims. Cronbach's alpha was 0.894 . The second dimension was related to the adaptability and had three claims. Cronbach's alpha was 0.817. The third dimension is related to the alignment and had three claims. Cronbach's alpha was 0.732 . The fourth dimension is related to the proactivity and consisted of four variables. Cronbach's alpha was 0.900 . The fifth dimension was related to the performance and consisted of six statements. Cronbach's alpha was 0.896 .

After testing the internal consistency, the factor analysis was performed in order to create five latent variables in order to facilitate handling in the later stage of analysis. All the results were satisfactory in accordance with the requirements of factor analysis. Take the same indicators on the validity of the factor analysis and the creation of variables related to business intelligence.

\section{Business Intelligence, Supply Chain Management and Marketing Decisions}

Making strategic marketing decisions represents a specific phase in marketing management. A research has shown that different models are used in practice for this purpose . According to the findings of the research, the most complex phase in making marketing decisions is linked to strategy implementation. A prerequisite of the effective marketing strategy considers different criteria which should be fulfilled- accuracy, measurability and applicability of information. Also, the important aspect is the suitability of information which is used in existing marketing information system of a company. Companies that satisfy those criteria make promptly decisions to eliminate market risks which also indicate the control role of Business Intelligence, through Supply Chain Management (SCM) at the tactical and strategic level. The basic hypothesis of the research is: Correlation concept of business intelligence and supply chain management is significant in making marketing decisions in order to preserve and strengthen marketing position.

Business Intelligence in Supply Chain Management contributes to the differentiation of the business entity. Market differentiation assumes constant collection of information of competitors' supply. Making strategic and tactical marketing decisions based on the application of Business Intelligence in the management of SCM is more efficient and responsible. Moreover, tools of the marketing mix should be adapted in accordance with strategies for making marketing decisions which are already mentioned above. The research has shown that making marketing decisions, based on Business Intelligence, is generally conducted through four phases. The first phase considers company's environmental analysis. The second phase includes defining frames of the final marketing decision. In 
the third phase correction decisions are made according to the feedback. In the fourth phase, consequences of the final marketing decision are estimated. In this process, Business Intelligence displays critical and strategic factors associated with key marketing business variables. Subsequently, the influence of the same factors on the marketing variables is estimated.

Marketing decision making should perform the function of maximizing the perception of the value of business entity market supply. The efficiency of data collection and analysis of competition in this sense are the imperative. Some authors define this process as market mechanism (Kotler) Competitor Intelligence System. The already mentioned research suggests that CIS should be adjusted to the company and the environment in which it operates. Positive experiences indicate a convenience of Business Intelligence analysis for making marketing decisions through five levels:

1. Early warning intelligence related to unusual market events;

2. Intelligence as a support for making strategic marketing decisions;

3. Intelligence as a support in tactical and operational decisions;

4. Evaluation of competitors;

5. Intelligence as a support in planning and making marketing strategies

Although, Herring (1999.) is the first one who, according to the results of the conducted research, formed important intelligence application areas for making marketing decisions, in this approach access stratification through multiple platforms is evident. The research conducted for the purpose of this study confirmed that relevant information about consumers, competitors, potential partners, suppliers and other influential groups is the first and the last line in defending market position. As a result, Business Intelligence protocol in making marketing decisions should be adjusted according to the table 1 :

Table 1. Recommended Business Intelligence protocol in making marketing decision

\begin{tabular}{|c|c|}
\hline 1. & $\begin{array}{c}\text { Estimation of tactical and strategic competitor's marketing } \\
\text { activities. }\end{array}$ \\
\hline 2. & Estimation of competitor's marketing programs. \\
\hline 3. & Guidelines for improving own marketing plan. \\
\hline 4. & Decisions related to the market development. \\
\hline 5. & Guidelines for improving a global image. \\
\hline 6. & Guidelines for shaping competitive marketing strategy. \\
\hline 7. & $\begin{array}{c}\text { Simulations and evaluation of the implementation of the new } \\
\text { marketing decision. }\end{array}$ \\
\hline
\end{tabular}

Source: Author of this work, according to conducted research, 2013.

\section{Correlation between Business Intelligence and Supply Chain Management important for marketing decisions}

After reducing the number of variables in the business intelligence and supply chain management investigated the association between latent variables related to business intelligence and supply chain management. The following matrix of Pearson's correlation coefficients was obtained in the table 2:

Table 2. Correlation between business intelligence and supply chain management

\begin{tabular}{|c|c|c|c|c|c|c|}
\hline & & SCM Agility & SCM Adaptability & SCM Alignment & SCM Proactivity & SCM Performance \\
\hline \multirow{3}{*}{$\begin{array}{c}\text { BI Reliability of data } \\
\text { and information }\end{array}$} & Pearson Correlation & $0.400^{* *}$ & $0.465^{* *}$ & $0.321^{* *}$ & $0.287^{* *}$ & $0.429^{* *}$ \\
\hline & Sig. (1-tailed) & 0.000 & 0.000 & 0.000 & 0.000 & 0.000 \\
\hline & $\mathrm{N}$ & 270 & 275 & 270 & 273 & 270 \\
\hline \multirow{3}{*}{$\begin{array}{l}\text { BI Access to data and } \\
\text { information }\end{array}$} & Pearson Correlation & $0.330^{* *}$ & $0.330^{* *}$ & $0.211^{* *}$ & $0.201^{* *}$ & $0.252^{* *}$ \\
\hline & Sig. (1-tailed) & 0.000 & 0.000 & 0.000 & 0.000 & 0.000 \\
\hline & $\mathrm{N}$ & 283 & 289 & 283 & 285 & 280 \\
\hline \multirow{3}{*}{$\begin{array}{l}\text { BI Advanced } \\
\text { analytics }\end{array}$} & Pearson Correlation & $0.247^{* *}$ & $0.380^{* *}$ & $0.162^{* *}$ & $0.397^{* *}$ & $0.295^{* *}$ \\
\hline & Sig. (1-tailed) & 0.000 & 0.000 & 0.004 & 0.000 & 0.000 \\
\hline & $\mathrm{N}$ & 274 & 280 & 274 & 278 & 273 \\
\hline \multirow{3}{*}{ BI Intuition and time } & Pearson Correlation & $0.420^{* *}$ & $0.473^{* *}$ & $0.313^{* *}$ & $0.296^{* *}$ & $0.402^{* *}$ \\
\hline & Sig. (1-tailed) & 0.000 & 0.000 & 0.000 & 0.000 & 0.000 \\
\hline & $\mathrm{N}$ & 282 & 288 & 282 & 285 & 280 \\
\hline \multirow{3}{*}{ Organization of BI } & Pearson Correlation & $0.308^{* *}$ & $0.333^{* *}$ & $0.235^{* *}$ & $0.242^{* *}$ & $0.265^{* *}$ \\
\hline & Sig. (1-tailed) & 0.000 & 0.000 & 0.000 & 0.000 & 0.000 \\
\hline & $\mathrm{N}$ & 276 & 282 & 275 & 280 & 275 \\
\hline
\end{tabular}


As can be discerned from the table above, in all cases there is a statistically significant correlation between variables that are related to business intelligence and variables related to supply chain management $(p<0.001)$. It may also be noted that the correlation coefficients are not very large.

\section{One-Way Anova of Business Intelligence With Respect to Activity, Employment and Legal Form of the Company}

It has been investigated the difference in the arithmetic means of business intelligence through one-way analysis of variance in relation to the sort of business of the company, number of employees, and legal form. Statistically significant differences in mean of business intelligence were obtained only when analyzing the activity of the company. It is shown in the Table 3:

Table 3. Analysis of variance of business intelligence with respect to the activity of the company

\begin{tabular}{|c|c|}
\hline Variable & Significance \\
\hline Source and reliability of data and information & 0.013 \\
\hline Access to data and information & 0.080 \\
\hline Advanced analytics & 0.061 \\
\hline Intuition and time & 0.927 \\
\hline Organization of business intelligence & 0.967 \\
\hline
\end{tabular}

Companies in the field of banking and finance, telecommunications and business services sectors have significantly more developed business intelligence in relation to companies related to the industrial production, trade, tourism and construction. These differences were found in the first three groups of questions related to business intelligence and were statistically significant.

As regards the number of employees and legal form of companies, there was no statistically significant difference regarding the application of the concept of business intelligence, and thus these results are not displayed.

Table 4. Analysis of variance of supply chain management regarding the activity of the company

\begin{tabular}{|c|c|}
\hline Variable & Significance \\
\hline Agility & 0.007 \\
\hline Adaptability & 0.062 \\
\hline Alignment & 0.001 \\
\hline Pro activeness & 0.394 \\
\hline Performance & 0.002 \\
\hline
\end{tabular}

\section{One-Way Anova of Supply Chain Management With Respect to Activity, Employment and Legal Form of the Company}

As can be seen from the table 4, above, all variables were statistically significant difference except pro activeness. As with business intelligence, better results were achieved in companies in financial services, telecommunications and business services. As with business intelligence, there was no statistically significant difference considering number of employees and legal form of enterprise, and thus these results are not displayed.

\section{Conclusion}

The research has shown that different approaches of Business Intelligence application for making marketing decisions through Supply Chain Management are used in practice. In each approach analysed above, the most complex phase is making decisions for marketing strategy implementation. It is necessary to ensure accuracy, measurability and applicability of information based on which marketing decisions are made. Companies that are included in the sample and which accomplish these criteria take prompt measures to eliminate market risks.

Business Intelligence in management of SCM contributes to the differentiation of a business entity. The research has shown that making marketing decisions based on Business Intelligence implementation in SCM management is efficient and business responsible. Making marketing decisions has to be in the function of maximizing perception of the value of business entity market supply.

The aim of the main hypothesis was to investigate the correlation concept of business intelligence and supply chain management, in the context of making marketing decision. Aggregate correlation coefficients show statistically significant correlation between the actual two sets of variables. Correlations dimensions that constitute the observed variables indicate some interesting elements:

- Quality of sources and reliability of data and information is effectively connected with better agility, adaptability and better performance of the companies analyzed;

- Use of intuition and time improvements based on the use of business intelligence is effectively connected with better agility, adaptability and better performance;

- Widespread use of advanced analytics is actually associated with better adaptability and greater supply chain pro activeness of the companies analyzed.

With the exception of the correlation between advanced analytics and compliance which is defined as low, all other mutual correlations are strong and statistically significant, so we can conclude that there is a positive correlation between 
the use of business intelligence and efficient supply chain management. It can be concluded that the relationship between business intelligence and supply chain management should be strengthened in order to maximize the correlation coefficients in the practical sense.

\section{REFERENCES}

[1] Akintoye, A., McIntosh, G., Fitzgerald, E.: A survey of supply chain collaboration and management in the UK construction industry, European Journal of Purchasing \& Supply Management, 2000., 6, p. 159-168.

[2] Copacino, W.: Better Supply Chain Collaboration Through Business Intelligence, Supply Chain Management Review, July 31, 2008.

[3] Davenport, Thomas D., Harris, Jeanne G.: Analytics at Work, Harvard Business School Press, Boston, 2010.

[4] Harvard Business Review on Managing Supply Chains, Harvard Business School Press, Boston, 2011.

[5] Hedin, H., Hirvensalo, I., Vaarnas, M.: The Handbook of Market Intelligence, John Wiley \& Sons, Chichester, 2011.

[6] Herring, Jan P.: Key Intelligence Topics: A Process to Identify and Define Intelligence Needs, Competitive Intelligence Review, 1999., 10 (2), p. 4-14.

[7] Howson, C.: Successful Business Intelligence, McGraw-Hill, New York, 2008.

[8] Hubbard, Douglas W.: How to Measure Anything, John Wiley \& Sons, New Jersey, 2010.

[9] Hugos, M.: Essentials of Supply Chain Management, 2nd ed., John Wiley \& Sons, New Jersey 2006.

[10] Jacoby, D.: Guide to Supply Chain Management, The Economist, London, 2009. World Scientific, New Jersey, 2008.
[11] Javorović, B., Bilandžić, M.: Poslovne informacije i business intelligence, Golden marketing - tehniočka knjiga, Zagreb, 2007.

[12] Kotzab, H., Seuring, S., Muller, M., Reiner, G. (Eds.): Research Metodologies in Supply Chain Management, Physica-Verlag, Heidelberg, 2005.

[13] Laursen, Gert H.N., Thorlund, J.: Business Analytics for Managers, John Wiley \& Sons, New Jersey, 2010.

[14] Lee, Hau L.: The Triple - A Supplly Chain, Harvard Business Review, October 2004., p. 102-112.

[15] Li, L.: Supply Chain Management: Concepts, Techniques and Practices, World Scientific, New Jersey, 2008.

[16] Miller, Jerry P.: Millenium intelligence: Understanding and Conducting Competitive Intelligence in the Digital Age, CYberAge Books, New Jersey, 2001.

[17] Min, S., Mentzer, J. T.: Developing and Measuring Supply Chain Management Concepts, Lournal of Business Logistics, 2004., 25 (1), p. 63-99.

[18] Panian, Ž. i sur.: Poslovna inteligencija: Studije slučajeva iz hrvatske prakse, Narodne novine, Zagreb, 2007.

[19] Panian, Ž.: Supply Chain Intelligence in E-Business Environment, WSEAS Transactions on Information Science and Applications, 2008., p. 210-221.

[20] Sahay, B. S., Ranjan, J.: Real time business intelligence in supply Chain analytics, Information management \& Computer Security, 2008., 16 (1), p. 28-48.

[21] Sharp, S.: Competitive intelligence advantage, John Wiley \& Sons, New Jersey, 2009.

[22] Slone, Reuben E., Dittmann, J. Paul, Mentzer, John T.: The new supply chain agenda, Harvard Business Press, Boston, 2010.

[23] Stubs, E.: The Value of Business Analytics, John Wiley \& Sons, New Jersey, 2011. 